\title{
PENGARUH METODE RESITASI (PENUGASAN) TERHADAP HASIL BELAJAR IPA SISWA KELAS V SDN 2 KEKERI TAHUN AJARAN 2021/2022
}

\author{
Silvia Ika Januarti ${ }^{1)}$, Mohammad Liwa Ilhamdi ${ }^{2 *}$, Husniati $^{3)}$ \\ 1), 3) PGSD, FKIP Universitas Mataram \\ ${ }^{2)}$ Pendidikan Matematika, FKIP Universitas Mataram \\ *Corresponding Author: liwa_ilhamdi@unram.ac.id
}

\begin{tabular}{l}
\hline ARTICLE INFO \\
\hline Article history \\
Received : September $12^{\text {st }}$, \\
Revised : November $17^{\text {st }}$, \\
Accepted : November $21^{\text {st }}$, \\
Keywords: \\
Recitation Methods (Assignment), \\
IPA, Learning Outcomes
\end{tabular}

\section{ABSTRACT}

This research aims to find out the influence of recitation methods (assignments) on the learning outcomes of students of class $\mathrm{V}$ of the School Year 2021/2022. This research includes experimental quasitype research with nonequivalent control group design type. The population in this study all students of class V in SDN 2 Kekeri numbered 36 students and the techniques used in sampling are saturated sampling techniques where VA classes as classes (controls) and VB classes as classes (experiments). The data collection technique in this study is a test of students' cognitive IPA learning outcomes. Student IPA cognitive learning outcome data analyzed using t-test. Separated Variance with a significant level of 5\%. Based on the results of the calculation of t-test statistical analysis obtained thitung results > ttabel which amounted to 4,680 > 2,034 which means there is an influence of recitation methods (assignment) on the learning outcomes of students IPA class V SDN 2 Kekeri School Year 2021/2022. Difference of 15.74 (78.29-62.55). Based on the calculation of the gain test on the student's IPA learning results, which was characterized by an average of $\langle\mathrm{g}\rangle$ experiment class of 0.562 medium categories, higher than the control class average of 0.288 low categories. Thus strengthening the conclusion that there is an influence on the use of recitation methods (assignment) on the learning outcomes of students of class V SDN 2 Kekeri School Year $2021 / 2022$.

ABSTRAK : Penelitian ini bertujuan untuk mengetahui pengaruh
metode resitasi (penugasan) terhadap hasil belajar IPA siswa kelas V
Tahun Ajaran 2021/2022. Penelitian ini termasuk penelitian
eksperimen jenis Quasi Eksperimental dengan tipe Nonequivalent
Control Group Design. Populasi dalam penelitian ini seluruh siswa
kelas V di SDN 2 Kekeri yang berjumlah 36 siswa dan teknik yang
digunakan dalam pengambilan sampel adalah tehnik sampling jenuh
dimana kelas VA sebagai kelas (kontrol) dan kelas VB sebagai kelas
(eksperimen). Teknik pengumpulan data dalam penelitian ini adalah
tes hasil belajar kognitif IPA siswa. Data hasil belajar kognitif IPA
siswa dianalisis menggunakan uji-t (t-test) Separated Varians dengan
taraf signifikan 5\%. Berdasarkan hasil hitung analisis statistik t-test
diperoleh hasil thitung >ttabel yaitu sebesar 4,680 > 2,034 yang berarti
terdapat pengaruh metode resitasi (penugasan) terhadap hasil belajar
IPA siswa kelas V SDN 2 Kekeri Tahun Ajaran 2021/2022. Perbedaan
sebesar 15,74 (78,29-62,55). Berdasarkan perhitungan uji gain
terhadap hasil belajar IPA siswa, yang ditandai dengan rata-rata <g>
kelas eksperimen sebesar 0,562 kategori sedang, lebih tinggi 
dibandingkan dengan rata-rata kelas kontrol yaitu 0,288 kategori rendah. Sehingga dengan demikian memperkuat kesimpulan bahwa adanya pengaruh penggunaan metode resitasi (penugasan) terhadap hasil belajar IPA siswa kelas V SDN 2 Kekeri Tahun Ajaran $2021 / 2022$.

\section{A. PENDAHULUAN}

Pendidikan merupakan usaha sadar dan terencana dalam mewujudkan suasana belajar dan proses pembelajaran agar peserta didik dapat secara aktif mengembangkan potensi dalam dirinya untuk memiliki kekuatan spiritual keagamaan, pengendalian diri, kepribadian, kecerdasan, akhlak mulia, serta keterampilan yang dimilikinya (Ilhamdi dkk., 2020:50). Pendidikan berfungsi dalam mengembangkan kemampuan dan membentuk watak serta kemajuan bangsa yang bermartabat dalam mencerdaskan kehidupan bangsa (Triwiyanto, 2015:24).

IPA merupakan mata pelajaran pokok dalam kurikulum pendidikan di Indonesia, termasuk pada jenjang pendidikan Sekolah Dasar. IPA atau yang sering disebut dengan sains berupaya untuk meningkatkan minat manusia agar dapat meningkatkan kecerdasan dan pemahamannya tentang alam seisinya yang penuh dengan rahasia yang tidak akan pernah ada habisnya. Ilmu Pengetahuan Alam adalah usaha manusia dalam memahami alam semesta melalui pengamatan yang tepat pada sasaran, serta menggunakan prosedur, dan dijelaskan dengan penalaran sehingga mendapatkan suatu kesimpulan (Susanto, 2016:166). Pembelajaran IPA bertujuan untuk mengembangkan pengetahuan serta konsep IPA yang bermanfaat sehingga dapat diterapkan dalam kehidupan, dan untuk meningkatkan kesadaran peserta didik agar ikut serta dalam memelihara, menjaga, melestarikan dan menghargai alam sekitarnya sebagai salah satu ciptaan tuhan (Samatowa, 2016:6).

Pada pembelajaran IPA, seorang guru hendaknya mengajar dengan cara melibatkan siswa secara aktif dalam proses pembelajaran. Pembelajaran IPA harus lebih menekankan pada pembelajaran yang berpusat pada peserta didik. Peserta didik harus dilibatkan secara langsung dan aktif dalam pembelajaran untuk memperoleh pemahaman yang lebih mendalam tentang alam sekitarnya (Sulviana dan Japa, 2018:22). Berdasarkan jenjang dan karakteristik perkembangan intelektual anak, maka penyajian konsep dan keterampilan dalam pembelajaran IPA harus dimulai dari nyata (konkrit) ke abstrak, dari mudah ke sukar dan dari sederhana ke rumit. Dengan kata lain, mulailah dari apa yang ada di sekitar atau lingkungan siswa dan yang dikenalnya, diminati serta diperlukan siswa dan anak-anak biasanya ingin mengerti fenomena-fenomena alam yang mengusik rasa ingin tahunya. Ilmu Pengetahuan Alam (IPA) ialah ilmu yang berkaitan dengan cara mencari tahu tentang alam secara sistemis dan juga bukan hanya penguasaan kumpulan pengetahuan yang berupa fakta-fakta atau konsep saja, akan tetapi juga merupakan proses penemuan (Ardhani dkk., 2021:171). Sehingga tugas guru adalah menciptakan dan mengoptimalkan suasana bermain tersebut dalam kelas agar menjadi media yang efektif untuk membelajarkan pelajaran IPA kepada siswa.

Metode pembelajaran menjadi salah satu upaya untuk menciptakan kondisi kelas yang mampu mengembangkan ranah sikap, pengetahuan dan keterampilan dari peserta didik. Permasalahan yang berkaitan dengan pembelajaran IPA meliputi hasil belajar masih 
didasarkan pada asumsi bahwa pengetahuan dapat dipindahkan secara utuh dari pikiran guru ke pikiran siswa atau dengan kata lain proses pembelajaran masih berpusat pada guru, mengakibatkan pasifnya siswa dalam proses pembelajaran karena pembelajaran hanya berpusat pada guru, sehingga siswa menjadi jenuh karena proses pembelajaran yang kurang berkesan dan menyenangkan. Hal ini tentu akan berdampak terhadap rendahnya hasil belajar khususnya pada mata pelajaran Ilmu Pengetahuan Alam (IPA). Hasil belajar diartikan sebagai tingkat keberhasilan peserta didik dalam mempelajari materi pelajaran di sekolah yang dinyatakan dalam bentuk skor (angka) yang diperoleh dari hasil tes mengenal sejumlah materi pelajaran tertentu (Susanto, 2013:5).

Peran guru dalam proses pembelajaran yaitu dengan menentukan permasalahan yang akan diajarkan serta memberikan arahan bagaimana cara menyelesaikan dan memecahkan masalah yang diberikan. Sedangkan peran siswa ialah menemukan jawaban terhadap masalah tersebut dengan bimbingan serta arahan dari guru yang intensif sesuai dengan perencanaan yang telah ditetapkan sebelumnya oleh guru (Trianto, 2013:147). Setiap kegiatan pembelajaran tentunya akan selalu mengharapkan agar menghasilkan pembelajaran yang maksimal (Sudjana, 2011:25). Kemampuan siswa dalam memahami dan menyerap informasi tentunya berbeda-beda tingkatannya (Irawati dkk., 2021:45). Dalam hal ini diperlukan metode yang dapat mempengaruhi hasil belajar siswa khususnya pada mata pelajaran IPA yang akan digunakan oleh guru. Karena metode mengajar merupakan suatu teknik atau cara yang ditempuh guru dalam menyampaikan bahan pelajaran kepada siswa dan melibatkan interaksi yang aktif dan dinamis antara guru dan siswa, pembelajaran menjadi lebih berkesan sehinga proses pembelajaran akan berpusat pada siswa dan tujuan belajar yang telah ditetapkan dapat tercapai.

Salah satu metode yang dianggap efektif dalam pembelajaran IPA yaitu metode resitasi (penugasan). Sagala (2013:219), mendefinisikan metode resitasi merupakan salah satu upaya untuk menanamkan konsep yang lebih dalam terhadap materi pelajaran. Metode pemberian tugas dan resitasi ini adalah satu cara penyajian bahan pelajaran dimana guru memberikan tugas tertentu agar peserta didik melakukan kegiatan belajar, kemudian tugas tersebut harus dipertanggungjawabkan atau dilaporkan kepada guru. Hal ini sejalan dengan pendapat Sinar (2018) bahwa melalui metode resitasi (penugasan), siswa dilatih untuk mencari sumber belajarnya sendiri, merangsang peserta didik untuk giat dan rajin dalam belajar, pengetahuan siswa akan semakin luas serta meningkatkan kreatifitas dalam memecahkan suatu masalah. Metode pemberian tugas dan resitasi ini diharapkan mampu mengaktifkan siswa dalam proses belajar serta dapat merangsang anak untuk aktif belajar baik secara individu maupun kelompok.

Metode Resitasi (penugasan) ini juga dapat mendidik siswa untuk meningkatkan rasa tanggung jawab siswa serta kemampuan siswa dalam memanfaatkan waktu belajar secara efektif dan efisien. Hal ini dikarenakan siswa dituntut untuk menyelesaikan tugas sesuai dengan waktu yang telah ditentukan dan harus mempertanggungjawabkan hasil tugasnya tadi kepada guru. Berbicara mengenai metode resitasi (penugasan), Sudjana (2011:81) menambahkan bahwa tugas atau resitasi tidak sama dengan pekerjaan rumah tetapi jauh lebih luas dari itu. Tugas dapat merangsang anak untuk lebih aktif belajar baik secara individual maupun kelompok. 
Dalam keberhasilan proses pembelajaran, peran aktif siswa untuk ikut terlibat secara langsung dalam kegiatan belajar sangat menunjang tercapainya tujuan pembelajaran, sehingga metode resitasi (penugasan) ini efektif dalam melibatkan siswa secara aktif (Halawa dan Chrismastianto, 2021:62). Dengan pemilihan metode resitasi (penugasan) ini diharapkan dapat mempengaruhi hasil belajar siswa, sehingga hasil belajar siswa dapat optimal dalam bidang studi IPA. Oleh karena itu, peneliti mengkolaborasikan metode yang pernah diterapkan oleh guru sebelumnya dengan metode resitasi. Resitasi adalah fase dimana siswa harus mempertanggungjawabkan tugas yang guru berikan sehingga materi yang guru ajarkan akan lebih dipahami oleh siswa.

Berdasarkan latar belakang masalah di atas, maka penulis mengadakan penelitian yang berjudul "Pengaruh Metode Resitasi (Penugasan) Terhadap Hasil Belajar IPA Siswa Kelas V SDN 2 Kekeri Tahun Ajaran 2021/2022”.

\section{B. METODE PENELITIAN}

Penelitian ini termasuk penelitian Eksperimen (Eksperimen Research). Penelitian eksperimen merupakan jenis penelitian yang bertujuan untuk mengetahui gejala atau pengaruh yang ditimbulkan karena adanya perlakuan. Jenis eksperimen semu (Quasi Eksperimental) merupakan jenis penelitian eksperimen yang bertujuan untuk mengetahui perbedaan kelas yang di beri perlakuan dengan kelas yang tidak diberi perlakuan (Sugiyono, 2017:107). Jenis penelitian eksperimen yang digunakan adalah Quasi Eksperimental Design tipe Nonequivalent Control Group Design.

Penelitian ini dilaksanakan pada semester genap di kelas V SDN 2 Kekeri, Kecamatan Gunungsari, Kabupaten Lombok Barat. Penelitian dilakukan terhadap dua kelas yakni kelas eksperimen dan kelas kontrol (pembanding). Pada kelas eksperimen diberikan perlakuan berupa pembelajaran yang menerapkan metode resitasi (penugasan), sedangkan pada kelas kontrol pembelajaran dilakukan dengan menggunakan pembelajaran sehari-hari (konvensional). Peneliti memberikan tes sebagai data awal untuk pre-test. Diakhir penelitian, untuk mendapatkan data akhir diberikan post-test terhadap kedua kelas. Sampel dalam penelitian ini adalah kelas V, dimana kelas VB sebagai kelas eksperimen dan kelas VA sebagai kelas kontrol dengan jumlah siswa masing-masing sebanyak 18 orang siswa. Sehingga jumlah sampel secara keseluruhan yaitu 36 orang siswa. Penentuan sampel dilakukan dengan menggunakan tehnik sampling jenuh (sensus) yaitu metode penarikan sampel bila semua anggota populasi dijadikan sebagai sampel (Arikunto, 2006:118).

Dalam penelitian ini instrumen yang digunakan berupa tes hasil belajar siswa. Adapun bentuk tes hasil belajar yang digunakan pada penelitian ini adalah tes objektif berupa pilihan ganda. Sebelum instrumen digunakan terlebih dahulu dilakukan uji coba tes butir soal menggunakan: (1) Uji Validitas, yaitu untuk menentukan validitas butir soal dalam penelitian digunakan rumus persamaan korelasi product moment dengan angka kasar pada taraf signifikan 5\%. Dimana jika $r_{x y} \geq r_{\text {tabel}}$, maka soal tersebut dikatakan valid. Jika $r_{x y}<r_{\text {tabel, }}$ maka soal tersebut dikatakan tidak valid. (2) Uji Reliabilitas, yaitu untuk mengetahui reliabilitas instrumen yang digunakan, maka dilakukan uji reliabilitas dengan tehnik split half yang di analisis dengan rumus Sperman Brown (Sugiyono, 2014:185). Selain itu instrumen pengumpulan data dalam penelitian ini juga menggunakan observasi, lembar observasi digunakan untuk mengetahui keterlaksanaan sintaks dalam pembelajaran dengan menggunakan metode resitasi (penugasan).

Teknik analisis data pada penelitian ini adalah teknik analisis kuantitatif. Teknik analisis data menggunakan uji-t (t-test). Sebelum dilakukan uji-t, terlebih dahulu dilakukan uji prasyarat yaitu uji normalitas dan uji homogenitas terhadap data yang telah diperoleh. 
Uji prasyarat dan uji-t dalam penelitian ini menggunakan analisis data: 1) Uji Normalitas Data, yaitu untuk mengetahui apakah data yang terkumpul berdistribusi normal atau tidak. Uji Normalitas dicari dengan mengunakan rumus uji Chi Kuadrat, pada taraf signifikan 5\%. 2) Uji Homogenitas, yaitu uji F digunakan untuk membuktikan kedua varian sampel tersebut homogen atau tidak. Uji Homogen dicari dengan menggunakan rumus uji varians, pada taraf signifikan 5\%. 3) Uji Hipotesis, yaitu untuk mengetahui apakah adanya pengaruh/perbedaan atau tidak, maka dilakukan Uji Hipotesis dengan menggunakan uji ttest Separated Varians pada taraf signifikan 5\%, dan selanjutnya untuk mengetahuai atau melihat besar pengaruh penggunaan metode resitasi (penugasan) terhadap hasil belajar siswa maka dilakukan dengan menggunakan uji gain ternormalisasi. Adapun rumus gain ternormalisasi yaitu:

$$
<g>=\frac{\text { Skor Posttest }- \text { Skor Pretest }}{\text { Skor Ideal }- \text { Skor Pretest }} \times 100 \%
$$

Tabel 1. Kriteria Interpretasi Gain Ternormalisasi

\begin{tabular}{cc}
\hline Nilai Gain & Interpretasi \\
\hline $0,70 \mathrm{~g} \geq 1,00$ & Tinggi \\
\hline $0,30 \leq \mathrm{g} \leq 0,70$ & Sedang \\
\hline $0,00<\mathrm{g}<0,30$ & Rendah \\
\hline $\mathrm{g}=0,00$ & Tetap \\
\hline$-1,00 \leq \mathrm{g} \leq 0,00$ & Terjadi Penurunan \\
\hline \multicolumn{2}{c}{ Sumber: Kesumawati dkk, dalam (faramida, 2018) }
\end{tabular}

\section{HASIL DAN PEMBAHASAN}

Metode resitasi (penugasan) adalah metode yang digunakan oleh guru dalam menyampaikan materi pelajaran melalui penugasan pada peserta didik baik lisan atau tulisan dalam rentang waktu tertentu agar siswa melakukan kegiatan belajar yang dapat mengaktifkan siswa untuk mempelajari sendiri suatu masalah dengan jalan membaca sendiri, mengerjakan soal sendiri, sehingga apa yang mereka pelajari dapat mereka rasakan berguna untuk mereka dan akan lebih lama mereka ingat. Penggunaan metode resitasi (tugas), diberikan dengan harapan agar siswa memiliki hasil belajar yang lebih baik, khususnya pada pembelajaran IPA.

Menurut Djamarah dan Zain (2013:85), metode resitasi (penugasan) ini juga merupakan metode penyajian bahan pelajaran dimana guru memberikan tugas tertentu agar siswa melakukan kegiatan belajar yang dapat merangsang anak untuk aktif belajar, baik secara individu maupun secara kelompok. Masalahnya tugas yang dilakukan oleh siswa dapat dilakukan didalam kelas, dilaboratorium, diperpustakaan, dibengkel, dirumah siswa, atau dimana saja asal tugas itu dapat dikerjakan.

Data penelitian yang digunakan adalah data hasil belajar IPA siswa yang diperoleh dari data post-tes di kelas eksperimen dan kelas kontrol. Data hasil belajar IPA siswa dapat dilihat pada tabel berikut. 
Tabel 2. Deskriptif Data Nilai Hasil Belajar IPA Siswa

\begin{tabular}{lcccc}
\hline Kelompok & $\begin{array}{c}\text { Jumlah } \\
\text { Siswa (N) }\end{array}$ & $\begin{array}{c}\text { Nilai } \\
\text { Tertinggi }\end{array}$ & $\begin{array}{c}\text { Nilai } \\
\text { Terendah }\end{array}$ & Rata-Rata \\
\hline Eksperimen & 18 & 94 & 54 & 78,29 \\
\hline Kontrol & 18 & 80 & 40 & 62,55 \\
\hline
\end{tabular}

Berdasarkan hasil penelitian yang dilakukan terhadap hasil belajar IPA siswa kelas V SDN 2 Kekeri, dimana proses pembelajaran dilaksanakan sebanyak 3x pertemuan pada kelas eksperimen dan kelas kontrol. Data keterlaksanaan pembelajaran menggunakan metode resitasi (penugasan) dengan menggunakan lembar observasi, diketahui bahwa pada kelas eksperimen memiliki skor keterlaksanaan pembelajaran sebanyak 54 pada pertemuan pertama, pada pertemuan kedua sebanyak 55, dan pada pertemuan ketiga sebanyak 56. Maka sesuai dengan kriteria yang telah ditetapkan dapat disimpulkan bahwa pada pertemuan pertama, kedua, dan ketiga secara berturut-turut memiliki kriteria baik, sangat baik dan sangat baik. Hal ini menunjukkan bahwa kegiatan pembelajaran dengan menggunakan metode resitasi (penugasan) terlaksana dengan sangat baik.

Berdasarkan respon siswa setelah melihat hasil observasi siswa berupa penggunaan metode resitasi (penugasan) diterapkan, dapat dikatakan telah mendapatkan respon yang baik, yakni siswa lebih antusias dalam mengikuti pembelajaran yang awalnya pada pertemuan pertama dan kedua aktivitas siswanya dikatakan baik dan untuk pertemuan ketiganya terlakasana dengan sangat baik. Hal ini menunjukkan bahwa penerapan metode resitasi (penugasan) dalam pembelajaran IPA dapat mempengaruhi hasil belajar siswa terutama dalam pembelajaran peristiwa alam (IPA). Berdasarkan hal tersebut, sesuai dengan yang dipaparkan oleh Djamarah dan Zain (2013:87), yang menambahkan bahwa metode resitasi atau pemberian tugas ini didasarkan agar mengaktifkan siswa baik secara individu maupun secara kelompok, serta pemantapan pengetahuan siswa dengan melakukan suatu tugas dan mendorong siswa belajar mandiri baik membaca, menulis, megerjakan soal dan sebagainya.

Pembelajaran dengan memberikan perlakuan berupa penggunaan metode resitasi (penugasan) dilaksanakan di kelas eksperimen sedangkan di kelas kontrol menggunakan pembelajaran sehari-hari (konvensional) di sekolah. Penelitian ini diawali dengan pemberian pretest pada kelas eskperimen dan kelas kontrol dengan tujuan untuk melihat kemampuan awal siswa. Rata-rata hasil pretest kelas eksperimen sebesar 50,33 sedangkan untuk kelas kontrol sebesar 47,38. Hasil ini menunjukan bahwa kedua kelas tersebut memiliki kemampuan awal yang relatif sama, sehingga dapat dilanjutkan untuk pemberian perlakuan. Selain itu, nilai tertinggi untuk kelas eksperimen adalah 86 dan terendah 27. Sedangkan untuk kelas kontrol nilai tertinggi yang diperoleh adalah 74 dan terendah 27.

Adapun hasil penelitian dari data pre-test dan post-test hasil belajar IPA siswa pada kelas eksperimen dan kelas kontrol yang dapat dilihat pada tabel 4.2 berikut:

Tabel 3. Hasil Belajar IPA Pre-test dan Post-test

\begin{tabular}{|c|c|c|c|c|c|}
\hline Kelompok & $\begin{array}{c}\text { Jumlah } \\
\text { Siswa (N) }\end{array}$ & Tes & $\begin{array}{c}\text { Nilai } \\
\text { Tertinggi }\end{array}$ & $\begin{array}{c}\text { Nilai } \\
\text { Terendah }\end{array}$ & Rata-Rata \\
\hline \multirow[t]{2}{*}{ Eksperimen } & \multirow[t]{2}{*}{18} & Pre-test & 86 & 27 & 50,33 \\
\hline & & Post-test & 94 & 54 & 78,29 \\
\hline \multirow[t]{2}{*}{ Kontrol } & \multirow[t]{2}{*}{18} & Pre-test & 74 & 27 & 47,38 \\
\hline & & Post-test & 80 & 40 & 62,55 \\
\hline
\end{tabular}


Berdasarkan tabel 4.2 diatas dapat disimpulkan bahwa nilai rata-rata kelas eksperimen dengan menggunakan metode resitasi (penugasan) lebih tinggi dari pada kelas kontrol yang menggunakan metode pembelajaran sehari-hari (konvensional). Terlihat dari nilai rata-rata post-test hasil belajar IPA siswa pada kelas eksperimen sebesar 78,29 dan kelas kontrol yaitu sebesar 62,55.

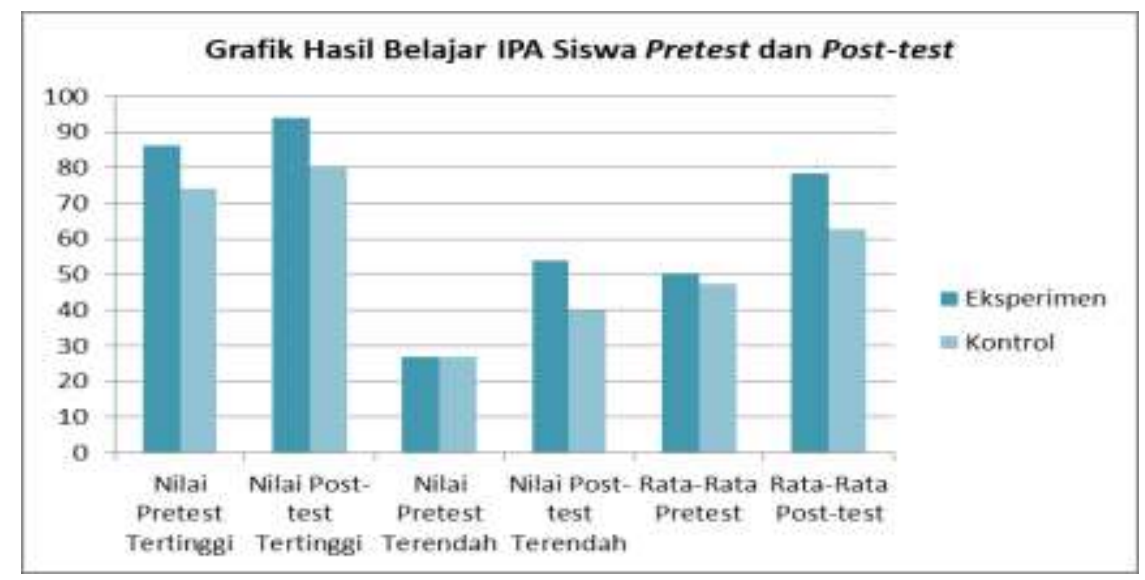

\section{Gambar 1. Diagram Data Hasil Belajar IPA Pretest-Posttest Siswa}

Dari data di atas, dapat diketahui bahwa hasil pre-test kelas eksperimen dan kelas kontrol memiliki kemampuan awal yang relatif sama. Dari data di atas, terlihat juga bahwa hasil belajar IPA siswa kelas eksperimen setelah diberikan perlakuan (post-test) berupa penggunaan metode resitasi (penugasan) lebih baik dibandingkan dengan hasil belajar kelas kontrol (posttest) yang tidak dberikan perlakuan. Berdasarkan data tersebut, terdapat perbedaan rata-rata nilai siswa antara kelas eksperimen dan kontrol setelah diberi perlakuan yang berbeda.

Setelah data hasil belajar IPA (pre-test dan post-test) siswa diperoleh, kemudian dilakukan uji normalitas data. Uji normalitas dilakukan terhadap data hasil pre-test dan post-test kelas eksperimen dan kelas kontrol untuk mengetahui apakah data kedua sampel tersebut terdistribusi normal atau tidak normal. Setelah data hasil uji normalitas kedua data hasil belajar IPA (pre-test dan post-test) siswa diperoleh bahwa keduanya berdistribusi normal, kemudian dilanjutkan dengan uji homogenitas data. Uji homogenitas digunakan untuk mengetahui apakah kedua kelompok sampel mempunyai varians yang sama (homogen) atau tidak.

Setelah kedua persyaratan terpenuhi yaitu kedua kelas tersebut menunjukkan bahwa data berdistribusi normal dan homogen, maka selanjutnya dilakukan uji hipotesis dengan menggunakan uji-t yang bertujuan untuk mengetahui adanya pengaruh penggunaan metode resitasi (penugasan) terhadap hasil belajar IPA siswa. Uji hipotesis dihitung dengaan menggunakan uji t-test Separated Varians pada taraf signifikan 5\%, berdasarkan data yang diperoleh, hasil $t_{\text {hitung }}=4,680$ yaitu lebih besar dari $t_{\text {tabel }}=2,034$, oleh karena itu dapat diketahui bahwa $t_{\text {hitung }}>\mathrm{t}_{\text {tabel }}$ sehingga dapat disimpulkan bahwa $\mathrm{H}_{\mathrm{a}}$ diterima, artinya hal ini menunjukkan bahwa adanya pengaruh penggunaan metode resitasi (penugasan) terhadap hasil belajar IPA siswa kelas V SDN 2 Kekeri Tahun Ajaran 2021/2022. Perbedaan atau selisih rata-rata sebesar 15,74 (78,29 - 62,55). Data selanjutnya dianalisis menggunakan nilai gain ternormalisasi, hasil dari gain ternormalisasi dapat dilihat pada tabel dibawah ini. 
Tabel 4. Hasil Perhitungan Analisis N-Gain Hasil Belajar IPA Siswa

\begin{tabular}{lcccccccc}
\hline \multicolumn{1}{c}{ Kelompok } & Tes & Xideal & Xmin & Xmaks & M & Gain & $\langle\boldsymbol{g}\rangle$ & Kriteria \\
\hline \multirow{2}{*}{ Eksperimen } & Pre-test & 100 & 27 & 86 & 50,33 & \multirow{2}{*}{27,96} & \multirow{2}{*}{0,562} & \multirow{2}{*}{ Sedang } \\
\cline { 2 - 10 } & Post-test & 100 & 54 & 94 & 78,29 & & \\
\hline \multirow{2}{*}{ Kontrol } & Pre-test & 100 & 27 & 74 & 47,38 & \multirow{2}{*}{15,17} & \multirow{2}{*}{0,288} & \multirow{2}{*}{ Rendah } \\
\cline { 2 - 10 } & Post-test & 100 & 40 & 80 & 62,55 & & \\
\hline
\end{tabular}

Berdasarkan tabel 4.8 diatas, dapat dilihat perbandingan hasil belajar IPA siswa antara sebelum dan sesudah pembelajaran dilaksanakan dengan menggunakan metode resitasi (penugasan), uji normalitas gain yang ditandai dengan rata-rata $\langle\mathrm{g}\rangle$ pada kelas eksperimen lebih tinggi dibandingkan dengan kelas kontrol, rata-rata $\langle$ g $>$ untuk kelas eksperimen yaitu 0,562 kategori sedang sedangkan di kelas kontrol rata-rata $\langle\mathrm{g}\rangle$ yaitu 0,288 kategori rendah. Sehingga dapat memperkuat kesimpulan bahwa adanya pengaruh penggunaan metode Resitasi (penugasan) terhadap hasil belajar IPA siswa kelas V SDN 2 Kekeri Tahun Ajaran 2021/2022.

Hasil uji hipotesis dan gain ternormalisasi di atas, menunjukkan bahwa pembelajaran dengan menerapkan metode resitasi (penugasan) memberikan pengaruh yang baik terhadap hasil belajar IPA siswa. Hasil belajar IPA siswa menjadi lebih baik setelah diberikan perlakuan penggunaan metode resitasi (penugasan) dari pada kelas yang diberi perlakuan dengan hanya menggunakan metode konvensional. Hasil dari penerapan penggunaan metode resitasi (penugasan) ini mengarahkan siswa untuk mencapai tujuan pembelajaran dan tentunya hasil belajar siswa menjadi lebih baik. Sejalan dengan pernyataan yang dikemukakan oleh Darmadi dalam (Sakila, 2019:84), bahwa penerapan metode resitasi atau pemberian tugas kepada siswa merupakan alternatif yang tepat dalam mengarahkan dan menyempurnakan tercapainya tujuan pembelajaran dengan partisipasi siswa secara langsung dan terlibat aktif dalam proses pembelajaran.

Penerapan metode resitasi ini dinilai berhasil dalam mempengaruhi hasil belajar siswa. Hasil dari penerapan metode resitasi (penugasan) ini, peserta didik hampir secara keseluruhan terlibat aktif dalam proses pembelajaran seperti pada saat siswa menyelesaikan tugas dengan baik serta pertanggungjawaban siswa terhadap tugas yang diberikan (Halawa dan Chrismastianto, 2021:71).

Hasil penelitian lain juga mengemukakan bahwa dengan penerapan metode resitasi bahwa semangat peserta didik di setiap pertemuan dan hasil belajar pada saat metode resitasi jauh lebih besar dari sebelumnya (Pertiwi dkk., 2018:122). Hasil belajar (kognitif) dan keterlibatan siswa lebih baik atau terjadi perubahan setelah diberikan perlakuan penerapan metode resitasi dari pada metode konvensional (Julianto dkk., 2015:9). Dengan penerapan metode resitasi (penugasan) ini juga dinilai berhasil dalam mendorong keterlibatan siswa secara langsung dan aktif, mampu memberikan pengaruh terhadap hasil belajar siswa serta kemampuan kognitif siswa dalam memahami dan mengolah informasi atau materi yang didapatkan.

\section{PENUTUP}

\section{Simpulan}

Berdasarkan hasil penelitian, analisis data, dan pembahasan maka dapat ditarik kesimpulan, yaitu terdapat pengaruh metode resitasi (penugasan) terhadap hasil belajar IPA siswa kelas V SDN 2 Kekeri Tahun Ajaran 2021/2022. Hal ini dibuktikan dengan penghitungan statistik dengan menggunakan rumus t-test separated varians dan gain ternormalisasi. Analisis statistik menggunakan rumus t-test separated varians diperoleh hasil thitung $>\mathrm{t}_{\text {tabel }}$ sebesar 4,680 > 2,034 pada taraf signifikan 5\% yang berarti bahwa terdapat pengaruh penggunaan metode resitasi (penugasan) terhadap hasil belajar IPA siswa, perbedaan sebesar 15,74 (78,29 - 62,55). Berdasarkan hasil uji gain terhadap hasil 
belajar IPA siswa, rata-rata nilai siswa pada kelas eksperimen dengan gain sebesar 0,562 kategori sedang, lebih tinggi dibandingkan dengan rata-rata gain kelas kontrol yaitu 0,288 kategori rendah. Dengan demikian memperkuat kesimpulan bahwa adanya pengaruh metode resitasi (penugasan) terhadap hasil belajar IPA siswa kelas V SDN 2 Kekeri Tahun Ajaran 2021/2022.

\section{Saran}

Berdasarkan pada hasil penelitian yang telah dilaksanakan dan kesimpulan yang telah diuraikan, maka saran peneliti adalah sebagai berikut: (1) Bagi Guru, berdasarkan hasil penelitian dengan menerapkan metode resitasi (penugasan) dapat menjadi alternatif dalam pembelajaran IPA. Misalnya dengan penggunaan metode resitasi (penugasan) ini, apabila diterapkan metode tersebut dengan optimal maka dapat memberikan pengaruh terhadap hasil belajar siswa, khususnya pada mata peljaran IPA; (2) Bagi Siswa, dengan penggunaan metode resitasi (penugasan) ini, diharapkan siswa lebih aktif dalam proses pembelajaran dikelas baik secara individu maupun kelompok, agar pembelajaran menjadi menyenangkan serta dapat meningkatkan kemampuan siswa; (3) Bagi Sekolah, bagi sekolah hendaknya mendorong guru untuk menggunakan metode pembelajaran yang dapat melibatkan siswa secara aktif dalam proses pembelajaran sehingga dapat merangsang anak untuk aktif dalam belajar, agar hasil belajar siswa dapat tercapai secara maksimal; dan (4) Bagi Peneliti lain, bagi peneliti selanjutnya, diharapkan dapat meneliti faktor-faktor lain yang dapat mempengaruhi hasil belajar siswa, sehingga tujuan pendidikan dapat tercapai.

\section{DAFTAR PUSTAKA}

Ardhani, A. D., Ilhamdi, M. L., \& Istiningsih, S. (2021). Pengembangan Media Pembelajaran Berbasis Permainan Monopoli Pada Pelajaran Ilmu Pengetahuan Alam (IPA) Kelas IV SD. Jurnal Pijar MIPA, 16(02), 170-175.

Arikunto, Suharsimi. (2006). Prosedur Penelitian (Pendekatan Kuantitatif, Kualitatif, dan R\&D). Jakarta : PT Rineka Cipta.

Djamarah, S. B \& Zain, A. (2013). Strategi Belajar Mengajar. Jakarta: PT Rineka Cipta.

Faramida, G., (2018), Pengaruh Pemberian Positive Reinforcement Terhadap Hasil Belajar IPA Siswa Kelas V SDN 8 Cakranegara Tahun Pelajaran 2017/2018, Skripsi S1, Program Studi Pendidikan Guru Sekolah Dasar, Universitas Mataram.

Halawa, E., \& Chrismastianto, I. A. W. (2021). Penerapan Metode Resitasi untuk Meningkatkan Keterlibatan Aktif Siswa Dalam Pencapaian Tujuan Pembelajran Sejarah Kelas X-IPS. Jurnal KAIROS, 1(1), 54-78. [online] available at https://ojs.uph.edu/index.php/KAIROS/article/view/3163

Ilhamdi, M. L., Novita, D., \& Rosyidah, A. N. K. (2020). Pengaruh Model Pembelajaran Inkuiri Terbimbing Terhadap Kemampuan Berpikir Kritis IPA SD. Jurnal Ilmiah Kontekstual, 1(02), 49-57.

Irawati, I., Nasruddin., \& Ilhamdi, M. L. (2021). Pengaruh Gaya Belajar Terhadap Hasil Belajar IPA. Jurnal Pijar MIPA, 16(1), 44-48.

Julianto., Amsia, T., \& M, S. (2015). Pengaruh Metode Belajar Resitasi terhadap Hasil Belajar Siswa. Jurnal Pendidikan dan Penelitian Sejarah, 3(2), 1-11.

Pertiwi, P. R., Basri, W., \& Aisiah (2018). Pengaruh Metode Resitasi Terhadap Hasil Belajar Siswa dalam Mata Pelajaran Sejarah di SMAN 13 Padang. Journal of Education on Social Science, 2(2), 114-124. [online] available at https://jess.ppj.unp.ac.id/index.php/JESS/article/view/141

Sagala, Syaiful. (2013). Konsep dan Makna Pembelajaran. Bandung: Alfabeta. 
Sakila. (2019). Metode Resitasi (Penugasan) dalam Pembelajaran Menemukan Gagasan dari Artikel dan Buku Melalui Membaca Ekstensif. Jurnal Ilmiah Kebahasaan dan Kesastraan, 7(1), 73-86. [online] available at https:/totobuang.kemdikbud.go.id/jurnal/index.php/totobuang/article/view/126/91

Samatowa, U. (2016). Pembelajaran IPA di Sekolah Dasar. Jakarta: PT Indeks.

Sinar. (2018). Metode Active Learning: Upaya Peningkatan Keaktifan dan Hasil Belajar Siswa. Yogyakarta: Deepublish.

Sudjana, Nana. (2011). Penilaian Hasil Proses Belajar Mengajar. Bandung: PT Remaja Rosdakarya.

Sugiyono. (2017). Metode Penelitian Pendidikan. Bandung: Penerbit Alfabeta.

Sulviana, A., Jufri, A. W., \& Japa, L. (2018). Pengaruh Model Pembelajaran 5e Terhadap Kesadaran Metakognitif dan Sikap Ilmiah Siswa pada Mata Pelajaran IPA di Mts 1 Mataram. Prosiding Seminar Nasional Pendidikan Biologi (Vol. 1, No. 1, pp. 20-25).

Susanto, A. (2013). Teori Belajar \& Pembelajaran. Jakarta: Prenada Media Group.

Susanto, Ahmad. (2016). Teori Belajar dan Pembelajaran di Sekolah Dasar. Jakarta: Prenada Media Group.

Trianto. (2013). Model Pembelajaran Terpadu, Bumi Aksara, Jakarta.

Triwiyanto, Teguh. (2015). Pengantar Pendidikan. Bumi Aksara. 